\title{
Determination of Heavy Metals and Physicochemical Parameters of Crude Oil Polluted Soil from Ohaji Egbema Local Government in Imo State
}

\author{
Ihenetu Stanley Chukwuemeka1, Ihenetu Francis Chukwuebuka ${ }^{2}$, Kalu Georgina Ijeoma1 \\ ${ }^{1}$ Chemistry Department, Imo State University, Owerri, Nigeria \\ ${ }^{2}$ Microbiology Department, Federal University of Technology, Owerri, Nigeria \\ Email: astancos41@gmail.com
}

How to cite this paper: Chukwuemeka, I.S., Chukwuebuka, I.F. and Ijeoma, K.G. (2017) Determination of Heavy Metals and Physicochemical Parameters of Crude Oil Polluted Soil from Ohaji Egbema Local Government in Imo State. Open Journal of Yangtze Gas and Oil, 2, 161-167.

https://doi.org/10.4236/ojogas.2017.23012

Received: March 10, 2017

Accepted: July 11, 2017

Published: July 14, 2017

Copyright $\odot 2017$ by authors and Scientific Research Publishing Inc. This work is licensed under the Creative Commons Attribution International License (CC BY 4.0).

http://creativecommons.org/licenses/by/4.0/

\begin{abstract}
The soil physicochemical parameter in Ohaji in Imo State, Nigeria was investigated using Ibeocha, Ekeugba, Awara, Mbirichi and Location as a case study. The result obtained from the soil analysis using standard methods shows that the concentrations of the heavy metals, $\mathrm{Pb}$ and $\mathrm{Fe}$ were highest in the soil from Ibeocha $(0.045 \mathrm{ppm})$ and Mbirichi $(0.126 \mathrm{ppm})$ which show high rate of industrial activity and oil spill in those areas. There was no remarkable change in $\mathrm{pH}$, but temperature followed the pattern of heavy metal concentration with acidic (lowest) values at the centre. The cation exchange capacity of the soil sample from location (14.066 ppm) shows that this soil sample has a lower contamination to compare to other soil samples from other location. Containment of the effects should be encouraged as soil from these sampling locations is contaminated due to oil spill.
\end{abstract}

\section{Keywords}

Physiochemical Properties, Soil, Heavy Metals

\section{Introduction}

Soil is considered to be the skin of the earth and interfaces with its lithosphere, hydrosphere, atmosphere and biosphere [1]. Soil consists of a solid phase (minerals and organic matter) as well as a porous phase that holds gases and water [1]. Accordingly, soils are often treated as a three-state system.

Most soils have a density between $1 \mathrm{~g} / \mathrm{cm}^{3}$ and $2 \mathrm{~g} / \mathrm{cm}^{3}$. Little of the soil of planet Earth is older than the Pleistocene and none is older than the Cenozoic, although fossilized soils are preserved from as far back as the Archean [2]. 


\section{Significance of the Study}

This study will go a long way to help determine the heavy metal concentration and other physiochemical characteristics of crude oil polluted soil obtained from Ohaji-Egbema in Imo state, Nigeria.

The aim and objective of this work are to assess the level of the selected heavy metals in soil and to determine the physiochemical parameters of polluted soil samples.

\section{Materials and Methods}

This research work was carried out among five different oil areas in Ohaji-Egbema local government area in Imo State. Ohaji-Egbema covers an area of approximately $958.010 \mathrm{~km}^{2}$ and it liesin the south/western part of Imo State and shares common boundaries with Owerri in the East [3].

\subsection{Sample Collection}

Five different Soil samples (Figure 1) were collected in Ohaji-Egbema community, Imo state. Soil samples were collected at different distances at a depth of $15 \sim 30 \mathrm{~cm}$ using an auger and kept in sterile plastic bags. Particle size composition was obtained by hydrometer method [4]. Each sample was labeled appropriately and transported to the chemical laboratory of the Imo state University Owerri, Nigeria, for analysis.

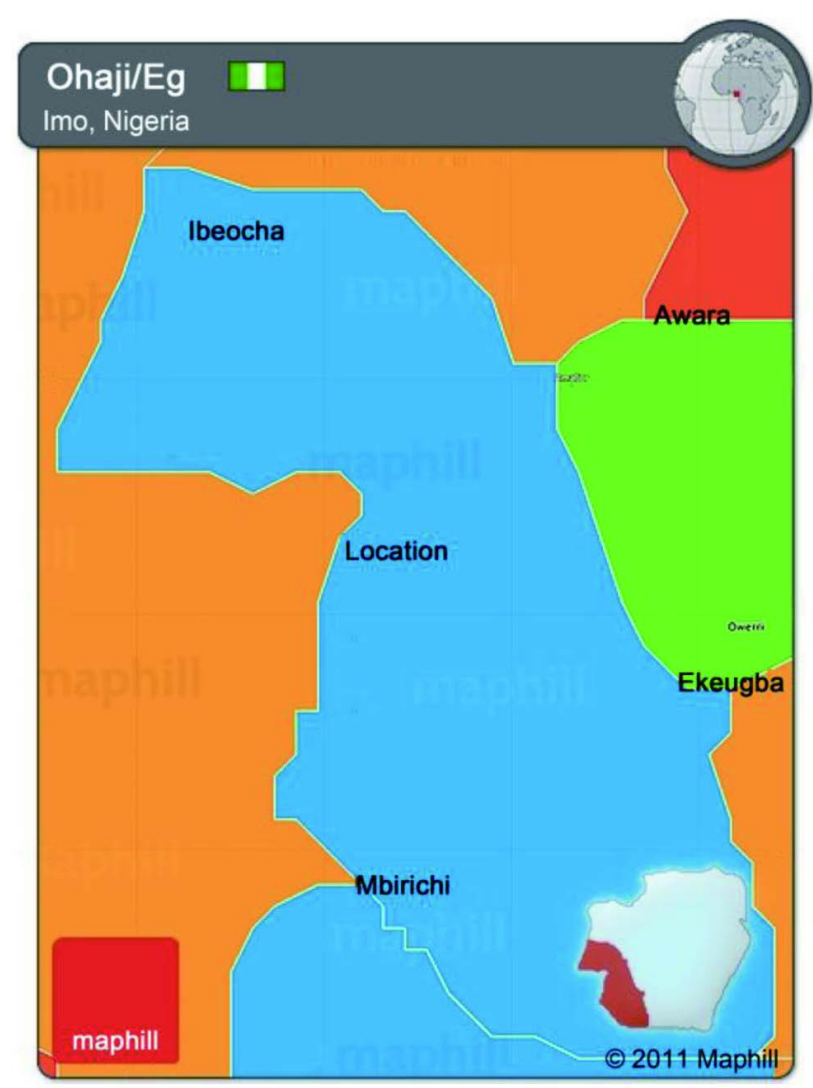

Figure 1. Geographical location of the site of sampling locations. 


\subsection{Sample Reduction}

Sample reduction was performed by quartering the sample to a convenient amount for analysis. The mixed composite sample were spread on clean plastic to form an even layer. The plastic was marked into quarters and the two opposite quarters are taken and mixed. The process is repeated until the two quarters selected give the desired sample size.

\subsection{Preparation and Treatment of Samples for Analysis}

Soil samples were air-dried and sieved with a $2 \mathrm{~mm}$ mesh [5]. The temperature of each sample was taken at the site by immersing the bulb of the thermometer in the soil and the reading in ${ }^{\circ} \mathrm{C}$ taken after one minute.

\subsection{Determination of Moisture Content}

$10 \mathrm{~g}$ of the sample was weighed into a porcelain dish. It was placed on a hot air oven at $105^{\circ} \mathrm{C}$ for two hours until all the moisture is driven off. The difference in weight is the amount of moisture in the soil. The moisture in the soil is calculated using the formula

$$
\text { moisture content }=\frac{\text { wet weight }- \text { dry weight }}{\text { dry weight }} \text {. }
$$

\subsection{Determination of Soil Texture}

$100 \mathrm{~g}$ of the sample was weighed into the quart bottle and filled with water up to the neck of the bottle. It was Shake to make sure that they settle simultaneously on the bottom of the quart bottle. It was allowed to stand overnight and the measure of the sand, clay and silt was calculated in percent.

\subsection{Determination of Electrical Conductivity}

The electrical conductivity was determined by using the HANNA HI8733 electrical conductivity. The electrical conductivity meter was with potassium chloride $(\mathrm{KCl}) .20 \mathrm{~g}$ of the sample was weighed into $500 \mathrm{ml}$ beaker and $200 \mathrm{ml}$ of water was added. It was allowed to stay for about 30 minutes and the electrode of the electrical conductivity was diped into the beaker and the reading was taking.

\subsection{Determination of Organic Matter}

This was determined by using the muffle furnace. $10 \mathrm{~g}$ of the sample was poured it into a porcelain dish and it was placed on a porcelain dish inside a muffle furnace and the temperature was set at $420^{\circ} \mathrm{C}$ for 2 hours. The sample was weighed using the electrical weighing balance to check the organic matter. Formular for calculating the organic matter.

$$
S O M=\frac{M o \times 100}{M_{D}}
$$

where: $M o$ is organic matter, $M_{D}$ is mass of dey soil, $M_{A}$ is mass of burned soil. 
$M o=M_{D}-M_{A}, M_{D}=Y_{2}-W_{D}$ (dry soil from the moisture content) $M_{A}=$ $M_{P A}-W_{D}$

\subsection{Determination of Soil Temperature}

This was determined by using the gardener's thermometer. The gardener's thermometer was inserted inside the soil sample and it was allowed to stay for about 5 minutes, the temperature of the soil was then checked.

\subsection{Reaction with Hydrochloric Acid}

$10 \mathrm{~g}$ of the sample was poured into a beaker and it was diluted with hydrochloric acid and distilled water in the ratio of 1:3. One drop of the diluted hydrochloric acid was dropped on the sample to check the reaction.

\subsection{Determination of the Soil $\mathrm{pH}$}

This is done by the use of JENWAY $3510 \mathrm{pH}$ meter which is calibrated using buffer 4 and buffer $7.10 \mathrm{~g}$ of the sample was weighed and pour into $250 \mathrm{ml}$ beaker and $100 \mathrm{ml}$ of water was added and stirred for about 30 minutes for 2 hours. The $\mathrm{pH}$ electrode was dipped into the beaker containing the sample and water and was left to stay for 5 minutes before taking the reading.

\subsection{Determination of Heavy Metals}

Heavy metal analysis was conducted using Varian AA240 Atomic Absorption Spectrophotometer according to the method of APHA 1995 (American public health association). $1 \mathrm{~g}$ of each sample was digested with aqua-regia for 5 days. The extract was centrifuged 30,000 for 15 mins and the heavy metal was determined using approparite calibration curves prepared in the same acid matrix with standard metal solutions for atomic absorption spectrophotometer

\section{Results}

The soil's characteristics that were used as indicators of the levels of pollution are presented in Tables 1-4. Properties like Electrical conductivity, moisture content, $\mathrm{pH}$, organic carbon, heavy metals, cation exchange capacity and visual tests were conducted and their results are shown in the various tables below.

Table 1. Visual characteristics.

\begin{tabular}{cccccc}
\hline & Ibeocha & Ekeugba & Awara & Mbirichi & location \\
\hline colour & PW & RB & RB & RB & LRB \\
moisture & moist & wet & moist & wet & moist \\
Size deg. & sand & sand & sand & sand & sand \\
Odour & HC & organic & HC & HC & Organic \\
E. con. & staining & staining & staining & staining & staining \\
RW.HCl & weak & strong & strong & strong & strong \\
\hline
\end{tabular}

where: $\mathrm{PW}=$ pinkish white, $\mathrm{RB}=$ reddish brown, $\mathrm{LRB}=$ light reddish brown, $\mathrm{HC}=$ hydrocarbon, Deg. = degradation, $\mathrm{E}$ con = evidence of contamination, $\mathrm{RW} . \mathrm{HCl}=$ reaction with $\mathrm{HCl}$. 
Table 2. Physicochemical characteristics.

\begin{tabular}{ccccccc}
\hline & $t / S D$ & $\mathrm{EC} / \mathrm{SD}$ & $\mathrm{MC} / \mathrm{SD}$ & $\mathrm{pH} / \mathrm{SD}$ & $\mathrm{OM} / \mathrm{SD}$ & $\mathrm{DP}$ \\
\hline Ibeocha & $28.09 \pm 0.3$ & $212 \pm 3$ & $21.5 \pm 1.1$ & $4.83 \pm 0.02$ & $4.23 \pm 0.9$ & $20-25$ \\
Ekeugba & $28.78 \pm 0.4$ & $187 \pm 2$ & $19.4 \pm 2.1$ & $4.85 \pm 0.20$ & $4.14 \pm 0.04$ & $20-30$ \\
Awara & $28.68 \pm 0.4$ & $169 \pm 1$ & $24.1 \pm 1.2$ & $4.74 \pm 0.02$ & $4.81 \pm 1.03$ & $20-30$ \\
Mgbirichi & $27.56 \pm 0.2$ & $151 \pm 2$ & $25.6 \pm 2.2$ & $4.83 \pm 0.01$ & $4.63 \pm 1.03$ & $20-30$ \\
Location & $28.12 \pm 0.5$ & $208 \pm 2$ & $22.3 \pm 1.2$ & $4.88 \pm 0.01$ & $4.02 \pm 1.02$ & $20-30$ \\
\hline
\end{tabular}

where: $\mathrm{EC}=$ electrical conductivity $(\mu \mathrm{S} / \mathrm{cm}), \mathrm{MC}=$ moisture content, $\mathrm{OM}=$ organic matter, $t=$ temperature, $\mathrm{SD}=$ standard deviation, $\mathrm{DP}=$ depth of sampling. Values are means of three replicates.

Table 3. Cation exchange capacity.

\begin{tabular}{cccccc}
\hline & $\mathrm{Ca} / \mathrm{ppm}$ & $\mathrm{Mg} / \mathrm{ppm}$ & $\mathrm{K} / \mathrm{ppm}$ & $\mathrm{Na} / \mathrm{ppm}$ & $\mathrm{CEC} / \mathrm{ppm}$ \\
\hline Ekeugba & 1.886 & 4.218 & 1.0035 & 0.660 & 7.767 \\
Ibeocha & 1.244 & 1.358 & 2.0053 & 0.953 & 5.560 \\
Awara & 2.514 & 3.167 & 2.0046 & 0.547 & 8.232 \\
Mbirichi & 5.367 & 3.536 & 1.019 & 1.137 & 11.059 \\
Location & 8.492 & 3.523 & 1.0034 & 1.048 & 14.066 \\
\hline
\end{tabular}

Where: $\mathrm{Ca}=$ calcium, $\mathrm{mg}=$ magnesium, $\mathrm{K}=$ potassium, $\mathrm{Na}=$ sodium, $\mathrm{CEC}=$ cation exchange capacity, $\mathrm{Ppm}=$ part per million.

Table 4. Concentration of heavy metals.

\begin{tabular}{ccc}
\hline Sample & $\mathrm{Pb} / \mathrm{RSD}$ & $\mathrm{Fe} / \mathrm{RSD}$ \\
\hline Ibeocha & $0.045(0.13)$ & $0.028(0.9)$ \\
Ekeugba & $0.00(0)$ & $0.049(0.21)$ \\
Awara & $0.008(0.07)$ & $0.038(0.01)$ \\
Mbirichi & $0.025(0.11)$ & $0.126(0.13)$ \\
Location & $0.014(0.08)$ & $0.021(0.014)$ \\
\hline
\end{tabular}

Where: $\mathrm{Pb}(\mathrm{ppm})=$ lead, $\mathrm{Fe}(\mathrm{ppm})=$ iron, $\mathrm{Ppm}=$ part per million. $\mathrm{RSD}=$ relative standard deviation.

\section{Discussions}

The summary of the result in Table 1 shows that all the soils bears the characteristics of oil soil, starting Ibeocha to Location. From the results obtained from Table 2, the Ibeocha sample recorded the highest electrical conductivity (212 $\mu \mathrm{s} / \mathrm{cm}$ ) and there is no much difference in the $\mathrm{pH}$ and temperature of the samples from the different locations, this is in line with the study made by Ololade et al., 2010, as seen in Table 5. The cation exchange capacity of the soil sample from location (14.066 ppm) is obtained to be higher than other soil samples (5.560 11.057 ppm), from Ibeocha, Ekeugba, Awara and Mbirichi. The cation exchange capacity as seen in Table 3. is high except for $\mathrm{Na}(\mathrm{ppm})$ which is not high in some of the sampling locations. The result obtained from Table 4 shows that there is no concentration of $\mathrm{Pb}$ in Ekeugba sample $(0.00 \mathrm{ppm})$ but the concentration of $\mathrm{Pb}$ in Ibeocha sample $(0.045 \mathrm{ppm})$ is higher than other concentrations of $\mathrm{Pb}$ from other sample locations. From Table 4, the concentration of Fe of the sample obtained from Mbirichi community $(0.126 \mathrm{ppm})$ is very high to 
compare to the concentration of Fe obtained from other sampling points. Figure 2 shows the bar chart indicating the level of Cation exchange capacity for all the samples. Some of these parameter were compared to a research done by Ololade et al. [8].

Table 5. Physiochemical properties of non-polluted soil in Edo State [6] [7].

\begin{tabular}{ccccccc}
\hline & $t$ & $\mathrm{EC}$ & $\mathrm{MC}$ & $\mathrm{pH}$ & $\mathrm{OM}$ & $\mathrm{DP}$ \\
\hline Ikpenme-OWO & 29.8 & 140 & 18.1 & 6.57 & 1.42 & $15-30$ \\
Ago Panu-Owo & 31.6 & 154 & 18.9 & 6.29 & 1.65 & $15-30$ \\
Ile-Oluji & 32.1 & 143 & 19.3 & 5.11 & 2.72 & $15-30$ \\
Bagbe-Ondo & 31.3 & 136 & 18.7 & 5.41 & 2 & $15-30$ \\
Oda-Akure & 32.5 & 128 & 17.5 & 5.91 & 3.71 & $15-30$ \\
\hline
\end{tabular}

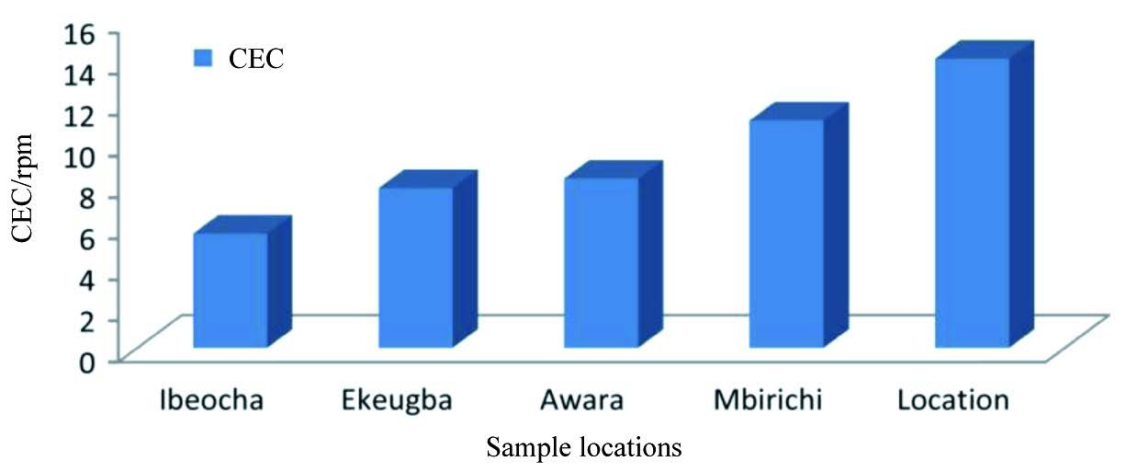

Figure 2. Bar chart showing the rate of Cation exchange capacity (CEC) in all samples.

\section{Conclusion}

From the analysis done so far, it can be concluded that the five samples obtained from Ibeocha community, Ekeugba community, Awara community, Mbirichi community and Location are contaminated. Therefore, in order to minimize the rate of spills in these areas (community), the following recommendations are suggested. The government of Nigeria should muster the political will to exact stricter respect for environmental laws and regulations by oil companies and a penalty plan established that requires oil companies whose activities cause excessive pollution or are ill-equipped to forfeit their licenses. Multinational and indigenous oil companies should ensure regular and constant inspection and maintenance of oil facilities to avoid accidental discharge or spillage of oil and other petroleum products. The current compensation regime in Nigeria has to be reviewed for it to be fair and adequate to meet the emergency needs and concern of those affected by pollution.

\section{References}

[1] White, R.E. (1997) Principles and Practice of Soil Science. 3rd Edition, Blackwell et al Inc., 152.

[2] Ajithkumar, P.V., Gangadhara, K.P., Manilal, P. and Kunhi, A.A.M. (1998) Soil Inoculation with Pseudomonas aeruginosa $3 \mathrm{~m}$ T Eliminates the Inhibitory Effect of 
3-Chloroand 4-Chlorobenzoate on Tomato Seed Germination. Journal of Soil Biology and biochemistry, 30, 1053.

[3] Lee, I., Kim, K. and Chang, Y. (2012) Heavy Metal Concentrations and Enzyme Activities in Soil. International Journal of Environmental Research and Public Health, 94, 406-411.

[4] Doran, J.W. and Parkin, T.B. (1994) Defining and Assessing Soil Quality and Effects of Soil Pollution. New Era Publishers, New York, 7-14.

[5] Allen, S.E., Grimshaw, P.H., Parkinson, J.A. and Quarmby, C. (1974) Chemical Analysis of Ecological Materials. Blackwell Scientific Publications, London, 41.

[6] Alex, D.W. (2008) Water Quality Studies of Nworie River in Owerri, Nigeria. Mississippi Academy of Sciences, 10-14.

[7] Bouyoucos, G.J. (1962) Estimation of Colloidal Material in Soils. Science, 64, 632.

[8] Ololade, I.A., Ajayi, I.R., Mohammed, O.Z. and Gbadamosi, A.E. (2010) A Study on Effects of Soil Physico-Chemical Properties on Cocoa Production in Ondo State. Journal of Modern Applied Science, 4, 5.

Submit or recommend next manuscript to SCIRP and we will provide best service for you:

Accepting pre-submission inquiries through Email, Facebook, LinkedIn, Twitter, etc. A wide selection of journals (inclusive of 9 subjects, more than 200 journals) Providing 24-hour high-quality service User-friendly online submission system Fair and swift peer-review system Efficient typesetting and proofreading procedure Display of the result of downloads and visits, as well as the number of cited articles Maximum dissemination of your research work

Submit your manuscript at: http://papersubmission.scirp.org/

Or contact ojogas@scirp.org 